Arkiv. Tidskrift för sambällsanalys, nr 6 (2016)

Festskriftsavdelning: Göran Therborn 75 år

\title{
Min förste magister i kritiskt tänkande
}

\section{Olle Svenning}

SAMMANDRAG: Olle Svenning lärde känna Göran Therborn i Lund som jämnårig radikal student på 1960-talet och skildrar i sin artikel Therborns spänningsfyllda förhållande till den svenska socialdemokratin. Från den unge Therborns korta tid som medlem i Lunds socialdemokratiska studentklubb och utgivningen av den av honom i huvudsak författade boken En ny vänster (1966), över Therborns och den "nya vänsterns" uppgående i C.H. Hermanssons reformerade vänsterparti, till den etablerade akademikern Therborns senaste analyser i backspegeln av "socialdemokratins århundrade" och det nya seklets politiska uppgifter i Ojämlikhet dödar (2016). Svenning ser det som hoppingivande att Therborn allt oftare bjuds in till socialdemokratiska organisationer för att presentera sina teorier.

NYCKELORD: Göran Therborn; socialdemokrati; En ny vänster; den "nya vänstern"; Ojämlikhet dödar.

PUBLICERINGSHISTORIK: Originalpublicering.

OLLE SVENNING är författare och journalist.

FÖRSLAG PÅ KÄLLANGIVELSE:

Svenning, Olle (2016) "Min förste magister i kritiskt tänkande", i Arkiv. Tidskrift för sambällsanalys, $\mathrm{nr}$ 6, s. 9I-I07.

DoI: http://dx.doi.org/I0.13068/2000-6217.6.5

(C) Olle Svenning/Arkiv förlag \& tidskrift 2016 (publicerad 7 oktober 20I6)

Artikeln distribueras enligt en upphovsrättslicens från Creative Commons:

Erkännande-Ickekommersiell-IngaBearbetningar 3.o Unported, som medger fri ickekommersiell användning och spridning i oförändrat skick så länge källan anges. 
Arkiv. Tidskrift för samhällsanalys är en sakkunniggranskad vetenskaplig tidskrift för samhällsvetenskap och historia. Samtliga artiklar publiceras fritt tillgängliga på:

$$
\text { www.tidskriftenarkiv.se }
$$

Beständig länk, DoI: http://dx.doi.org/IO.13068/2000-62I7

Den här artikeln finns tillgänglig i följande format:

PDF \& HTML: via beständig länk, DOI: http://dx.doi.org/I0.13068/2000-62I7.6.5 EPUB: ingår i e-boksutgåva av numret, ISBN: 978 9I 79242794 TRYCK: ingår i bokutgåva av numret, ISBN: 978 9I 7924280 O

Grafisk utformning och sidnumrering är identisk i pdf och tryck.

Samtliga artiklar i nr 6 (20ı6) nås via beständig länk, DOI: http://dx.doi.org/I0.13068/2000-6217.6

Arkiv. Tidskrift för samhällsanalys ISSN: 2000-62I7 (för elektronisk resurs) ISSN: 2000-6225 (för tryckta nummer)

ges ut av

Stiftelsen Arkiv för främjande och spridning av samhällsvetenskaplig och historisk forskning

genom

Arkiv förlag \& tidskrift

Box 1559

SE-22I OI Lund

ВESÖK: L Gråbrödersg 3 c, ipg

TEL: 046-I3 3920

ARKIV FÖRLAG: arkiv@arkiv.nu·www.arkiv.nu

TIDSKRIFTEN ARKIV: red@tidskriftenarkiv.se · www.tidskriftenarkiv.se

ANSVARIg UTGIVARE \& CHEFREDAKTÖR: Sven Hort

ADMinistrativ RedaKtör: David Lindberg

ReDAKTörer: Paavo Bergman, Lisa Kings, Zhanna Kravchenko 


\section{Min förste magister i kritiskt tänkande}

\section{OLLE SVENNING}

Ett halvsekel har förflutit sedan vårt första möte på Kulturen i Lund. Vi drack kaffe, åt wienerbröd och bestämde att vi skulle skriva ett program för en ny svensk vänster. Göran Therborn var äldst: han hade fyllt 23 år. Det var inte bara av åldersskäl han var vår ledande teoretiker. Göran var redan i tjugoårsåldern extremt beläst; han kunde blixtsnabbt hänvisa till ett exakt citat ur Marx I8:e brumaire och han vecklade ut den europeiska vänsterkartan för oss andra: Här börjar vi. Det var i Storbritannien och kompassen var New Left Review.

Den plattform Therborn valde för vårt arbete bars upp av den skånska socialdemokratin. Landets mäktigaste och en gång dess mest radikala distrikt. Partiets förste store ledare kom därifrån. Han hette August Palm, var skräddare och hade agiterat i såväl Tyskland som Danmark. En europé alltså.

Vår lilla grupp av partiideologer bestod av fyra personer och vi blev alla medlemmar i den socialdemokratiska studentklubben. Några av oss, jag själv exempelvis, omfattade den socialdemokratiska ideologin, i dess svenska version. Andra, kanske främst Göran, ville omforma socialdemokratin efter sin egen teoretiska modell.

Några år efter vårt första möte i Lund kom boken En ny vänster ut (Rabén \& Sjögren 1966). Vår studiegrupp hade hunnit splittras. Jag hade flyttat till regeringskansliet och skrev tal åt statsminister Tage Erlander. Kontakten med Therborn skars dock aldrig av. Göran var organiserad 
socialdemokrat och i det partiet är åsiktsskillnader helt acceptabla, så länge den organisatoriska lojaliteten förblir intakt.

En ny vänster, förvisso starkt influerad av New Left Review och Perry Anderson, placerade sig ideologiskt långt bortom den svenska arbetarrörelsens traditioner. De historiska motsättningarna mellan partiets höger och vänster formades vanligtvis av de internationella relationerna. Den gamla socialdemokratin förblev lojal mot den alltmer uttunnade och provästliga Andra internationalen och dess efterföljare: trogen demokrati och västvärlden. Försiktigt reformistisk, angelägen om att bygga starka organisationer, särskilt den fackliga. Partivänstern kom efter den ryska oktoberrevolutionen att underordna sig Moskva, de 2I teserna och de leninistiska principerna. De tidiga försöken att utveckla ett slags vänstersocialism krossades snabbt.

Therborn vred bort dessa båda vänsteralternativ från den politiska scenen. Han dömde ut såväl den försiktiga socialdemokratiska praktiken som den oreflekterade Sovjetunderkastelsen. I en sensationell mening dömde Therborn ut socialdemokratins mest ikoniska ledare Per Albin Hansson - han kallade honom fäaktig. Per Albin, ledaren under krigsåren, folkhemmets försångare, reducerades till en tämligen enkel samförståndsman, villig till uppgörelser med storfinansen men obenägen att använda socialdemokratins formidabla parlamentariska styrka till socialistisk samhällsomvandling.

Kommunistpartiet, "Moskvapåsarna", var absolut inget alternativ: intellektuellt torftiga, parlamentariskt ett bihang till socialdemokratin. Therborn sökte inspiration hos de italienska kommunisterna, PCI, organisatoriskt tämligen likt SAP. Dess ledare Palmiro Togliatti hade, trodde vi då, brutit med Sovjet och han anslöt sig reservationslöst till de antistalinistiska resolutionerna från tjugonde partikongressen 1956. Togliatti ville befria kommunismen från Moskvacentralismen: han förordade "polycentrism". Vänsterpartierna skulle välja sin egen nationella väg till socialismen. Åsikter, traditioner, politiska metoder - allt kunde utvecklas självständigt och i ett slags dialog mellan partierna och de olika vänsterrörelserna. En revolutionär ståndpunkt efter ett halvsekel av kallt krig mellan socialdemokrater och kommunister.

Therborn och sociologen Gunnar Olofsson, som stod varandra politiskt och personligt mycket nära, ringade in den svenska vänsterns styr- 
kor och svagheter. Det självklara centrum, värt att erövra eller åtminstone påverka, var socialdemokratin, som under den perioden hade stöd av 45-50 procent av väljarna och som regerat landet i över 30 år. Partiets hegemoni inom arbetarrörelsen var drygt ett halvsekel gammal. Partiets styrka hade att göra med organisationen och med dess väldiga medlemsantal. SAP samlade runt en miljon medlemmar och fackföreningsrörelsen (LO) organiserade runt 90 procent av arbetarna. Parti och fack var sammansvetsade genom kollektivanslutning.

Therborn och Olofsson såg också möjligheter i den reformistiska arbetarrörelsens parallella samhälle. I det fanns pionjärverksamhet, ungdomsrörelse, begravningsbyråer, konstföreningar, bostadskooperation, hyresgäströrelse, bildningsorganisationer. En struktur som påminde om det röda Wien.

Ett sådant väldigt politiskt-organisatoriskt bygge måste kunna formas om, laddas av uppror och radikalism. Så, förstod jag, resonerade Therborn. Han gjorde snabbt upp med ABF, som tillsammans med studentklubben i Malmö genomförde en studieverksamhet kring Marx och marxismen. Något sådant hade $\mathrm{ABF}$ inte gjort sedan långt före andra världskriget. Therborn föreläste liksom andra från studentklubben, men också traditionella socialdemokrater gav lektioner om marxismen, bland dem den tillförordnade intellektuellt orienterade chefredaktören för tidningen Arbetet, normalt sett ett försiktigt socialdemokratiskt språkrör, alltid lyhört för regeringens synpunkter.

Med ABF som hjälp kunde också antikolonialismen få en plats inom folkbildningen, hur märkligt det än kan låta. Tillsammans bjöd Therborn och jag in representanter för algeriska FLN och något förbryllade mötesdeltagare fick på klockren franska höra talas om slaget i Alger och kampen mot kolonialismen. Det förebådade den kommande Vietnamaktivismen. Studentklubben i Lund kom, bland annat via Therborn, att få en starkt internationalistisk hållning. Tiden var antikolonialistisk, engagemanget mot apartheidsystemet i Sydafrika växte, också inom den fackliga rörelsen. Här fanns också en länk mellan den radikala unga vänstern och arbetarrörelsen. Vi hade dock större ambitioner än så. Göran Therborn skrev i klubbens namn ett upprört brev till Harold Wilson och fördömde Labourregeringens ovilja att krossa det vita Rhodesia och dess ledare Ian Smith. Vi fick inget svar från Wilson. 
Therborn såg möjligheter att påverka socialdemokratins mer perifera rörelser, exempelvis Hyresgästernas Riksförbund. Där fanns potential för att bekämpa marknaden, den privata byggindustrin, markspekulationer. Inom hyresgäströrelsen fanns långlivade rötter förankrade i socialdemokratisk opposition.

Det fanns, alldeles självklart, en viss misstänksamhet från de skånska arbetarekommunerna mot studentklubben och Therborn. Den skånska arbetarrörelsen släpar på en hundraårig historia av skepsis mot akademiker, mot "intelligensarna" som partiets förste agitator August Palm kallade dem. Socialdemokratin, liksom dess tidningar, skulle vara en rörelse för arbetare, ledd av arbetare. Så löd Palms formel.

Dock förekom ett visst vardagssamarbete. Mötesplatser etablerades mellan den socialdemokratiska kommunen och Therborns studentrörelse. Vi drog våra stenciler på arbetarekommunens kontor och vi drack kaffe med partiombudsmännen. En av dem var känd som en särskilt framgångsrik "kommunistjägare". Han var skarpsinnig, beläst och normalt sett skeptisk till "vänsterdeviationism". Therborn bjöd honom att föreläsa om arbetarrörelsen och kommunismen. Under eftersitsen berättade den upprymde ombudsmannen, som också var finansministerns rådgivare, om övervakning, registrering av kommunister och fackliga utrensningar. Vi fick tio år före IB-skandalen veta det mesta om den socialdemokratiska partiapparatens övervakningssystem av dissidenter, men vi förstod nog inte riktigt vad vi hade fått höra eller så tog vi partispioneriet för givet.

Therborn och vi andra i den socialdemokratiska studentrörelsen var inte kollektivt anslutna till partiet, till SAP. Principen var att studentorganisationerna skulle vara självständiga, dessutom skulle de ha rätt att vara medlemmar i den radikala Clartérörelsen. Ett sådant medlemskap ledde normalt sett till uteslutning ur partiet. Dock hade alltid studentklubben självklar rätt att delta på de socialdemokratiska partimötena och distriktssammankomsterna.

I Skåne hölls dessa distriktssammankomster på det väldiga danspalatset Amiralen. Distriktet dominerades av den fackliga rörelsen, förhållningssättet var utpräglat ouvrieristiskt, praktiskt, inriktat på löntagarnas dagspolitiska intressen. I mitten av 6o-talet höll Therborn ofta 
tal inför den här församlingen. Hans talarkonst var utredande, långsam och fylld av referenser som var helt okända för majoriteten av kongressdeltagarna. Hans attacker på partiets praktik och teori var också nya. Vanligtvis riktade partivänstern sin kritik mot försvarsutgifter, mot oviljan att erkänna DDR, mot ogeneröst u-landsbistånd eller mot brist på socialiseringskrav. Therborn kritiserade klassamarbetet, alliansen mellan arbetarrörelse och kapital, och han gick till attack mot statens oerhörda subventioner till det privata näringslivet. Kritiken riktade sig helt enkelt mot den praktik som i decennier burit upp socialdemokratin, förmått den att skapa en historisk kompromiss, där kapitalägarna och företagarna lämnades ifred för att skapa tillväxt för att sedan ge arbetarrörelsen vissa möjligheter att fördela överskottet, utjämna inkomster och bygga ut sociala trygghetssystem.

Therborn attackerade den sortens maktordning, som i princip accepterade privatkapitalismen och som förutsatte en nära allians mellan arbetarrörelsens ledarskikt och privatkapitalet, förkroppsligat av familjen Wallenberg. Therborn argumenterade mot klassamhällets över- och underordning. Han var inte bara marxistiskt beläst, han hade också stått nära den syndikalistiska rörelsen. Det frihetliga tänkandet var centralt och här fanns en länge stark men med tiden dold tradition inom socialdemokratin. Dess främste teoretiker Ernst Wigforss, finansminister under lång tid, stod nära den frihetliga socialismen, inspirerad såväl av Marx tänkande som av brittiska fabianiter och progressiva liberaler.

Under de långa, sega debatterna på Amiralen förlorade Therborn naturligtvis alla avgörande omröstningar. Men hans argument satte avtryck: arbetarrörelsen orienterade sig tillbaka till den etiska socialism och den moraliska ekonomi som var grundläggande i Ernst Wigforss tänkande. Ett till att börja med försiktigt men med tiden alltmer självmedvetet uppror inleddes mot bristen på jämlikhet, och under sent 6o-tal knöt arbetarrörelsen an till en jämlikhetsideologi som programmatiskt uttrycktes i kravet: "ökad jämlikhet”. Språkligt egendomligt men ideologiskt välfungerande. Det teoretiska och praktiska arbetet leddes av Alva Myrdal och utfördes i allt väsentligt av den socialdemokratiska studentgeneration som Therborn tillhörde. LO, med sina stora resurser, drev på arbetet. Under en period uppstod den allians mellan akademiker och 
en stark fackföreningsrörelse som format socialdemokratins särskilda framgångsperioder. Det var säkert den sortens samverkan som lockat Therborn till socialdemokratin.

Therborn blev i Vietnamkrigets tidiga skede för första gången känd också för en större svensk publik; det följde av hans roll som sociolog. Han tog nämligen på sig uppgiften att pröva mediernas rapportering om det så kallade Tonkinbuktintermezzot - det som gav USA alibi att inleda massbombningarna över Vietnam. Medier som rapporterat kritiskt om USA:s uppgifter om Tonkin stämplades som vänstervridna och en av Sveriges Radio inhyrd statsvetarprofessor gav det borgerliga etablissemanget rätt. Therborn pulvriserade professorns analys och han gjorde det med hjälp av hålkort, innehållsanalys och uppgifter om vad som faktiskt inträffat i Tonkin.

Kanske var det första gången Therborn förenade sin roll som politisk aktivist med sin profession som vetenskapsman. Han tillhandahöll en teoretisk bas för den tidiga Vietnamrörelsen. På ett enklare och mer perifert plan höll vi i kanslihusvänstern kontakt med Therborn och den unga vänstern. Vi samlades i en villa där en av Sveriges blivande EUambassadörer höll öppet hus.

Det fanns länge en obesvarad fråga inom 6o-talets studentvänster: Skulle den fortsätta att verka inom socialdemokratin eller skulle den förbereda ett nytt parti? Therborn kunde berätta för oss i Lund om Frankrike, om hur PSU brutit med socialistiska SFIO, sönderslitet och korrupt efter sitt stöd till kolonialkrigen i Indokina och Algeriet. Men vi behövde inte blicka mot Paris: i grannländerna växte vänstersocialistiska partier sig allt starkare. Aksel Larsen, den gamle danske kommunisten och motståndsmannen, bröt med sitt förflutna, rörde sig från kommunism till vänstersocialism. Han kallade det nybildade partiet ett socialistiskt folkparti. $\mathrm{Vi}$ visste inte då att han under nazistisk tortyr hade angivit en stor del av kommunist- och motståndsrörelsens ledning. För en del av oss var Aksel Larsen en politisk förebild, en man som stod för socialismens tredje väg, den frihetliga. Larsen blev en flitig gäst hos det socialdemokratiska studentförbundet. Dit kom också Finn Gustavsen, ledare för det norska socialistiska folkpartiet. Gustavsen hade brutit med vänsterns absoluta budord, han hade nämligen medverkat till att störta en "arbetarregering". 
Therborn kände säkert en lockelse att medverka till att bilda ett svenskt socialistiskt folkparti, men han såg skillnaderna mellan den svenska situationen och den som rådde i Norge och Danmark. Båda dessa nationer var anslutna till Nato, de var delaktiga i den västliga försvars- och maktordningen. USA-lojaliteten var stor. Båda tycktes dessutom vara på väg att överväga medlemskap i EU (EEC). I Sverige fanns ett massivt folkligt stöd för alliansfrihet och neutralitet och redan 196I hade Tage Erlander sagt nej till svenskt medlemskap i EEC. Det var därmed omöjligt att bilda ett politiskt parti upproriskt mot gällande internationella ordning. Dessutom genomgick den svenska socialdemokratin en radikalisering. Partiets kritik mot den amerikanska världsordningen och mot USA:s krig i Vietnam förstärktes efter att Olof Palme mer eller mindre övertog ansvaret för utrikespolitiken från statsminister Tage Erlander, känslomässigt bunden till USA och nära vän med vicepresidenten Hubert Humphrey.

Den svenska vänstern var på väg att förändras när boken En ny vänster kom ut 1966.

Socialdemokratin skulle det året göra ett av sina sämsta val, med en uppmätt förlust på 8,2 procent jämfört med kommunalvalet I962. Ett partiledarskifte förbereddes och Olof Palme var på väg att ersätta Tage Erlander. För många, inte minst för den intellektuella vänstern, förebådade detta en radikalisering av arbetarrörelsen.

Kommunisterna genomgick en än mer genomgripande omvandling. Hilding Hagberg - enligt Therborn medlem i det kommunistiska partiets ölklubb - avlöstes av C.H. Hermansson - ekonom, utpräglat intellektuell och med betydande lyhördhet för den nya vänstern. Hermansson hade redan 1965 givit ut boken Vänsterns väg och han hade kartlagt den svenska storfinansen i ett epokgörande arbete.

De politiska villkoren och det politiska klimatet var lovande för den unga vänstern men också strategiskt komplicerat. Therborn skriver, en aning komiskt, i förordet till En ny vänster, att Hermansson verkligen är välkommen. Dock bör han inte bli för framgångsrik för det är, skriver Therborn, "vårt parti” som ska stå för förnyelse och radikalism. Kan han någonsin ha trott på detta? Var inte brytningen med socialdemokratin lika självklar som alliansen med Hermanssons parti? 
Hermansson och hans skikt inom kommunistpartiet tog starka intryck av den nya vänstern, men det gjorde också den socialdemokratiska partiledningen. Det fanns en rak förbindelseled mellan partiledningen och den nya vänstern: motståndet mot "avideologiseringen". I En ny vänster genomför Göran Therborn en hård uppgörelse med Herbert Tingsten, statsvetare, chefredaktör och den tidiga efterkrigstidens helt dominerande debattör. Under mitten av 6o-talet drev Tingsten tesen att ideologierna var döda, att en utbredd harmoni rådde och att vi levde i en lycklig demokrati där folk inte ens behövde bry sig om att rösta. Dessa teser kallade Therborn totalitära. Han menade att Tingsten försökte eliminera klassdimensionen i politiken och att han bortsåg från över- och underordning. Therborn attackerade också de då dominerande intellektuella attityderna om behovet av "trolöshet", ett närmande till nihilistiska föreställningar. Det är en individualiserad och uppgiven livshållning som står i konflikt med vår uppgift som medborgare och vårt ansvar för samhällsutvecklingen, menar Therborn.

Tage Erlander tog intryck av Therborns argument. "Läs här och använd den analysen. Fast lite försiktigare”, sa Erlander när han bad mig skriva en recension av Tingstens bok om ideologiernas död. Erlander, en mer utpräglat intellektuell politiker än Olof Palme i den meningen att han lyssnade till sina motståndares argument, intresserade sig för den unga Lundavänstern, kanske också för att han en gång i tiden tillhört en sådan gemenskap. Han ville träffa Therborn och medlemmar av den socialdemokratiska studentklubben. Jag tror däremot inte att Erlander anade att tiden närmade sig för student- och arbetaruppror i Europa.

Erlander gav mig i uppgift att ordna ett möte med den radikala Lundavänstern. Det skulle äga rum efter en statsministerafton i Lund. Erlander var väl förberedd; han hade läst första numret av den nya tidskriften Zenit. Ämnet var blandekonomi och på omslaget hade a:et ersatts av ett i. Blindekonomi. "Mycket intressant", sa Erlander. "Mycket bättre än den där André Gorz", skrev han senare i sin dagbok. Han noterade också: "Therborns En ny vänster är ett ambitiöst försök att tolka intelligenta ungdomars protest mot långsamheten i förändringen.”

Mötet mellan den åldrande statsministern och den unga vänstern blev katastrofalt. Therborn felbedömde alldeles mötets karaktär och 
möjlighet. I stället för att diskutera ekonomins organisation, kapitalismens koncentration eller vänsterns villkor började Therborn och övriga studenter att rasa över en ministerutnämning. Docent Camilla Odhnoff från Lund hade utsetts till minister trots att hon studerat i Sydafrika och uttalat sig obetänksamt om apartheid. Denna personfråga klibbade fast vid hela mötet och efteråt sammanfattade Erlander: "Therborns anförande var uppseendeväckande vansinnigt. [- - ] Besynnerligast av alla Göran Therborn. Han talar med en omständighet och med upprepningar som gör honom nästan outhärdlig."

Den gamla statsministern tog därmed avsked av den nya vänsterns främste företrädare. Olof Palme, Erlanders efterträdare, höll ut längre, trots att han ofta kritiserades särskilt hårt av vänstern. Palmes tal innehöll ofta ett avsnitt om den unge Marx och alienationen och han hänvisade gärna till Gramscis analyser om hegemonins makt och villkor. Analyserna var sällan särskilt utförliga, citaten var snarare små blinkningar till den unga vänstern, vilken för övrigt var alltmer kritisk till Marx ungdomsskrifter.

Det var Palme som skulle tvingas mäta sig med C.H. Hermansson. Vem av dem skulle vinna den unga radikala opinionen?

Till att börja med fungerade vänsteralliansen om kritiken mot USA:s krig i Vietnam. Palme distanserade sig redan 1965 från den amerikanska politiken. Men den politiska dynamiken i tiden sprängde alla försök till bred vänstersamverkan. Den unga vänstern lockades alltmer av det folksocialistiska projektet, av Larsen och Gustavsen. Nya tidskrifter och tidningar startades. Organisationer, om än löst sammansatta, skapades för att förena socialdemokratisk vänster med reformisterna inom det gamla kommunistpartiet. Därmed äventyrades allt politiskt samarbete mellan socialdemokratin och den nya vänstern. Sveriges socialdemokratiska arbetareparti har i huvudsak alltid varit ett politiskt-ekumeniskt parti, öppet och tillåtande för många åsiktsriktningar men stenhårda motståndare till all fraktionsverksamhet. Organisatorisk lojalitet måste gälla. Nyvänsterns majoritet förenade sig med C.H. Hermansson. Therborn blev programförfattare åt Hermanssons parti, andra steg in i riksdagen.

De politiska följderna blev paradoxala. Betydande delar av den unga vänsterns samhällskritik och teoretiska förnyelse kom att integreras också 
inom den traditionella arbetarrörelsen. Det var dock tveklöst Vänsterpartiet kommunisterna som blev bas för den unga, nya vänstern. Röstmässigt förblev dock styrkeförhållandena som förr. Ja, det blev till och med så att Hermansson och hans allierade i slutet reducerades till en spillra (3,o procent) medan Socialdemokraterna fick stöd av över 50 procent av väljarna (andrakammarvalet 1968). Ideologiskt och teoretiskt hade den nya vänstern lyckats, parlamentariskt misslyckades den.

Det var det stora politiska utropstecknet för en segrande socialdemokrati. Det var också slutet för den epoken. Samtidigt betydde 1968, uppfattat som symbol, att den intellektuella vänstern, inspirerad av Marx, av brittiska New Left, av Gramsci och Gorz, försvann i riktning mot periferin. En mer revolutionär, aktivistisk, antiparlamentarisk och med tiden sekteristisk vänster tog över. Det gamla kommunistpartiet rämnade. Kvar i Hermanssons parti fanns Göran Therborn och en grupp andra akademiker och intellektuella. Som organisatorisk kraft var den nya vänstern förbrukad. Sorgesamt jämförde de sig med Il Manifestogruppen, som rensades ut av det italienska PCI.

Therborn lockades en kort tid av det revolutionära upproret och han bröt med sin ungdoms frihetligt socialistiska uppfattningar. Med tiden valde han att vårda sin internationella akademiska karriär. Då och då förenades den med analyser av tillståndet inom socialdemokratin. 1979 skrev Therborn tillsammans med några andra forskare om socialdemokratisk parlamentarisk praktik och jämlikhetens tillstånd i Sverige. Deras slutsats var starkt negativ:

Våra resultat reser starka tvivel på den parlamentariska hypotesen, på antagandet att fyra årtionden av socialdemokratisk regering har haft en avgörande betydelse för de relativa mått av jämlikhet och välfärd som finns i Sverige idag. I stället tenderar de att ge stöd åt klasshypotesen, att tidigare klassrelationer reproducerats snarare än omvandlats av den parlamentariska situationen $1932-76 .{ }^{1}$

Denna svarta summering av ett halvt sekel av socialdemokratisk regeringspolitik exkluderade dock inte Therborn från det stora arbetarpartiet.

I. Göran Therborn, Anders Kjellberg, Staffan Marklund och Ulf Öhlund, "Sverige före och efter socialdemokratin: en första översikt", i Arkiv för studier i arbetarrörelsens historia nr I5-I6 1979. En ombruten och översedd nyutgåva av det slutsålda numret finns fritt att ladda ner från http://www.arkiv.nu/Portals/o/pdf/Arkivi5ı6.pdf (citatet återfinns på s. $30-3 \mathrm{I})$. 
Socialdemokratin har en tradition av att välkomna sina dissidenter. De som bröt med partiet vid tiden för ryska revolutionen återvände med få undantag; de flesta blev män i stat och parti. Therborn återvände aldrig till socialdemokratin, däremot fick han ett uppdrag av partiet: att skriva ett kapitel i den bok Socialdemokraterna gav ut till hundraårsminnet av partiets grundande.

Hundraårsdagen inföll 1989. Den Sovjetdominerade kommunismen var på väg att falla sönder i Öst- och Centraleuropa men också i imperiets själva centrum. Det skulle få djupgående verkningar också för socialdemokratin. Men 1989 var ännu den reformistiska arbetarrörelsen en betydande politisk kraft. I Sverige regerade socialdemokratin om än alltmer mödosamt och under allt större slitningar mellan en liberal falang och en mer traditionell. Konflikterna mellan partiet och den fackliga rörelsen var hårdare än på flera decennier. Therborns uppsats måste läsas mot denna tidsbakgrund. Vad fanns - så kan frågan ställas - att rädda av arbetarrörelsen när den sovjetkommunistiska tiden var utmätt? Therborn gav sitt kapitel en egenartad rubrik: "Nation och klass, tur och skicklighet. Vägar till ständig (?) makt" (i Socialdemokratins sambälle, Tiden 1989). Observera frågetecknet. Två år senare var makten förlorad.

Therborn skriver lidelsefritt. Tjugofem år efter En ny vänster har han placerat sig i betraktarens och vetenskapsmannens roll, inte den politiska aktivistens. Han vill förstå socialdemokratins framgång, inte göra uppror mot partiet. Han utgår från ett enkelt konstaterande: "Den svenska socialdemokratin har skaffat sig en parlamentarisk maktställning som saknar motstycke i den moderna demokratins historia." Therborn uppehåller sig vid socialdemokratins särskilt starka nationella karaktär som en förklaring till framgångarna. I det bryter han mot partiets självbild. Enligt den är historien fylld av internationellt arbete, från Hjalmar Brantings insatser i Socialistinternationalen, som nedrustare inom Nationernas förbund och som Nobels fredspristagare. Den traditionen levde vidare genom Olof Palme, hans starka tro på nord-syd-dialog, nedrustning och antiimperialism, uttryckt i kritiken av USA:s Vietnamkrig. I Therborns text förekommer Palme endast som den som desarmerade kärnkraftsfrågan inom partiet. 
Therborn ser inte det aktivistiska draget i den svenska utrikespolitiken. För honom har neutralitetspolitiken främst varit praktisk, realpolitisk och konsensusdominerad: "Neutralitetspolitiken hade brett folkligt stöd trots de kompromisser som regeringen tvingades till, både med avseende på eftergifterna för Hitler-Tyskland och på flyktingpolitiken.”

Mot socialdemokratins föreställning om sig själv som en internationell rörelse ställer Therborn nationalismen, partiet förknippas med nationen och nationens intresse. Den medelålders Therborn citerar till och med gillande Per Albin Hansson, som den unge Therborn hade föraktat:

I en tid av oro och omvälvningar i folkens och staternas liv, då demokratiska och parlamentariska styrelseformer trängts undan eller hotas av diktatoriska, har det synts mer än vanligt angeläget att $\mathrm{i}$ vårt eget land trygga den folkliga självstyrelsen genom att skapa bredast möjliga underlag för regeringens arbete.

Så sa Per Albin Hansson 1936 då socialdemokraterna samverkade med bondeförbundet, bland annat för att hålla borta hot från nazistiskt eller fascistiskt orienterade politiska rörelser. Therborn finner den formulering som särskilt starkt bar upp socialdemokratins framgångsdecennier: ”Nationell politik blev i Sverige en välfärdspolitik." Och välfärdspolitik blev LO-politik, summerar Therborn.

Han diskuterar inte riskerna med ett sådant nationellt projekt - det gjorde ingen på den tiden. Det skulle riskera att blåsas bort av den ekonomiska globaliseringen, av den digitala tekniken. Av EU-medlemskap och av en dramatiskt växande global låglönemarknad. Medan demokratin slog sönder sovjetsystemet, så fick marknaden det socialdemokratiska projektet att haverera. Som en reaktion levde mellankrigstidens demoner upp på nytt. Den hotade europeiska arbetarklassen tenderade alltmer att sätta den nationella, till och med etniska, striden före klasskonflikterna.

I Therborns text från 1989 finns inte denna spänning mellan klass och nation, annars en klassisk konfliktyta i hela arbetarrörelsens historia. Socialdemokratin hade helt enkelt förmått förena den nationella strategin med framgångsrik klasspolitik.

Socialdemokraterna hade, visar Therborn med övertygande valsociologiskt material, förblivit ett utpräglat klassparti, periodvis med över 70 procent av arbetarklassens röster bakom sig. Therborn pekar ut ett sär- 
eget fenomen, karaktäristiskt för den svenska arbetarrörelsen. LO-organisationen blev till en "monolitisk socialdemokratisk kader". Politiska motståndare hölls utanför styrelser och fackklubbarnas ledning, kommunisterna bekämpades intensivt. Facket mobiliserades under valrörelser för socialdemokratin. ”Fackliga ledare blev våra ambassadörer på arbetsplatserna", som en samtida förbundsordförande uttryckte saken. Detta var i decennier möjligt på grund av den fackliga kollektivanslutningen till socialdemokratin; de mobiliserade pengar, aktivister, röster och medlemmar till partiet. I Therborns text finns en liten kritisk blinkning till dem som tar avstånd från den sortens allians mellan parti och fack. Therborn presenterar Metallordföranden Ernst Blomberg (I863I9II) som "fackföreningsrörelsens portalgestalt".

Blomberg bekämpade intensivt varje form av facklig kollektivanslutning till Socialdemokraterna. Han stod redan i ı9oo-talets början för den "rena" fackliga politiken. Arbetarklassen skulle vara enig, inte splittrad mellan olika politiska rörelser. En självklar syndikalistisk hållning.

Trots kollektivanslutningen begränsade socialdemokratin inte sin ambition till att vara ett uttalat klassparti - det hade förmått integrera delar av medelklassen med hjälp av en generell välfärdspolitik, gynnsam också för tjänstemannagruppernas intressen. Partiet hade, som Hjalmar Branting önskade redan i slutet av I80o-talet, blivit ett folkparti. Förmågan att smälta samman klasspolitik och allmänna folkliga ambitioner kopplar Therborn samman med de starka svenska folkrörelserna: "Folkrörelsetraditionen förbinder klasspolitik, och därigenom socialdemokratin, med djupa rötter i det svenska folkets historia.” Med folkrörelsekaraktären följer organisation, noggrannhet, försiktighet, förhandlingsvilja och uthållighet, betonar Therborn. Det tänkandet ligger nära det som Hjalmar Branting uttryckte med termen "utvecklingstanken". Folket, arbetarklassen, skulle förberedas, utbildas och göra sig berett att ta över samhällsstyret. Det var så demokratin förankrades. Den tesen ställdes i motsats till den leninistiska föreställningen om ett arbetarklassens avantgarde.

Jag läser om Therborns 25-sidiga uppsats ett par gånger för att övertyga mig om att jag uppfattat textens huvudbudskap: Therborn tar farväl till 
ungdomens upproriska syn på socialdemokratin. Ibland skriver han helt enkelt segrarens historia och då kan det bli något problematiskt. Jag fäster mig vid hans tämligen välvilliga skildring av hur socialdemokratins partiledning 1917-1918 på en gång lyckades avvärja revolution och i riksdagen driva igenom en rösträttsreform som i princip gav allmän och lika rösträtt. Tiden präglades av hungerkravaller, massiva protestdemonstrationer och folkligt missnöje, och partipolitiskt kom arbetarrörelsens revolutionära gren att uteslutas ur socialdemokratin. De folkliga protesterna var mycket känsliga för socialdemokratin eftersom partiet under perioder ingick i regeringen. Therborn menar att partiledningen lyckades avvärja protesterna och ta sig ur sitt politiska dilemma genom att bygga en stark och centralistisk arbetarkommitté som vann förtroende hos upproriska arbetare samtidigt som den satte skräck i den höger som bekämpade rösträtten. Arbetarkommittén kunde misstänkas förbereda samhällsomvälvning och hot om revolution skrämde högern att acceptera demokratin.

Det är en vacker men väl schematiskt enkel skildring. Det uteblivna upproret har delvis materiella orsaker: livsmedelsbristen blev mindre skriande I9I8 och dämpade upprorsstämningarna. Den revolutionära vänstern gjorde allvarliga taktiska misstag genom att kopiera den bolsjevikiska politiken och till och med uttala sig för proletariatets diktatur. En oppositionell vänster som dämpade de långsiktiga målen för att i stället försöka mobilisera arbetarna för de dagspolitiska kraven om arbete, bröd och värdigt liv skulle bli betydligt farligare för socialdemokratin, som var belastad av att sitta i regeringen under hungerperioderna. Den internationella situationen med revolutionen i Ryssland och främst utvecklingen i Tyskland skrämde också den svenska högern och monarkin till eftergifter. Socialdemokratin har, som Therborn senare påpekar, haft tur.

Ralph Miliband, en av idégivarna till En ny vänster, skriver i sin bok Marx och politiken (Bonniers 1980) att Marx och flertalet av hans efterföljare visade ett svagt intresse för politik och för parlamentariskt arbete och parlamentariska villkor. Förhållningssättet kan överföras till den svenska socialdemokratins historia. Det var partivänstern som ifrågasatte det parlamentariska arbetet; det måste vara underordnat parti- och klasspolitiken, menade partivänsterns ledare Zäta Höglund. Den unge 
Therborn skulle hålla med, däremot är Therborn av 1989 förstående för det politiska och parlamentariska spelet och för det han kallar samförståndsinvitationen, socialdemokratins förmåga att utan alltför utslätade kompromisser välja lämpliga politiska allianser: ibland bönderna för att genomföra krispolitik, ibland kommunisterna för att vinna stöd för sociala reformer, exempelvis pensionssystemet. Therborn letar sig dock inte fram till det som alltid varit själva kärnfrågan för all socialdemokratisk strategisk och taktisk politik: att hålla högern utanför inflytande. För Hjalmar Branting gällde det att isolera högern för att kunna genomföra allmän och lika rösträtt. Tage Erlander kunde trygga sina 23 år som statsminister genom att ständigt underblåsa oenigheten mellan den borgerliga centern och högern. Så skulle välfärdssystemet tryggas och en viss socialdemokratisk hegemoni upprätthållas.

När Göran Therborn mitt i sin mest intensiva vetenskapliga karriär får i uppdrag av Socialdemokraterna att reflektera över partiets historia skriver han välvilligt försonat, med distans förstås. Han sammanfattar:

Utifrån utomordentliga utgångsbetingelser och med en stor portion tur kan den svenska socialdemokratin ändå sägas ha förtjänat sin makt med egen skicklighet. I varje fall inom landet har SAP varit oöverträffat i nationsbyggande, arbetarklasspolitisk intresserealism och praktisk konsekvens, i partitaktisk manöverförmåga, i sakpolitisk kompetens och organisatorisk kraft.

Jag läser formuleringarna som delar av en välvillig dödsruna över arbetarrörelsens 1900-tal, det som också kallats socialdemokratins århundrade. Den nya tiden ställer helt andra frågor. För Therborn handlar det om att försöka förstå det nya årtusendet. Han anger sina perspektiv i sin studie Världen. En inledning (Liber 20I2). Hans prolog innehåller den nyfikna och ödmjuka formuleringen: ”De flesta av oss är nybörjare i mänsklighetens planetariska terräng. [...] Och vi är alla nybörjare i tjugohundratalet.” I denna nya värld betraktas den europeiska arbetarrörelsen i backspegeln, som en del av den värld som försvunnit. Therborn upprepar sin respekt i artikeln "Klass i det tjugoförsta århundradet":

Också den reformistiska delen av I900-talets arbetarrörelse har givit oss ett bestående arv; det har bidragit till ett av de största regeringspartierna i de flesta länder i Europa i dag. Nu finns en fackföreningsrörelse av verkligt internationell 
omfattning [- - ] Välfärdsstaten - en stat med medborgerliga sociala rättigheter - är 1900-talsreformismens viktigaste bedrift. ${ }^{2}$

Han är pessimistisk eller realistisk om den europeiska arbetarklassens förmåga att påverka framtiden: "De utvecklade ekonomierna avindustrialiseras och deras arbetarklasser har splittrats, besegrats och berövats tron på sig själva.” Nya problem skjuts i förgrunden, särskilt ekologin. Det är i de hotande miljökatastroferna som Therborn ser den klassiska motsättningen i det kapitalistiska produktionssättet.

Det betyder inte att de stora politiska uppdragen har gått förlorade för arbetarklassen, bara att nya allianser måste byggas. Therborn arrangerar de krafter som skulle kunna förenas mot den globala kapitalismen för "ett annat samhälle". Arbetarklassen är en del av en sådan världsomspännande front men den är inte längre en förtrupp. Till den hör de radikala rörelserna i Latinamerika, kanske en upprorisk välorganiserad kinesisk facklig rörelse och definitivt unga radikala rörelser som Podemos och Syriza. Möjligen också en missnöjd, socialt misshandlad medelklass, men den kan också gå i helt andra politiska riktningar.

De gemensamma politiska uppgifterna för en sådan allians har Therborn presenterat i boken Ojämlikhet dödar (Arkiv förlag 20I6; på engelska 2013 som The killing fields of inequality). Det är ojämlikhetens "dödsfält" som måste desarmeras.

Och detta dödsfält sträcker sig över hela världen, till de fattiga i Londons eländiga kvarter och till Indiens landsbygd där hälften av befolkningen lever under fattigdomsstrecket. Från massarbetslöshetens Spanien och Grekland till migrantarbetare i Sydostasien och Kina.

Therborn hänvisar endast försiktigtvis till Marx, däremot mer eftertryckligt till Amartya Sen och dennes grundläggande tes om människovärdet: varje människa måste ha rätt till grundläggande hälsovård, utbildning, värdigt arbete, anständig bostad och ska också kunna delta i det offentliga livet.

Mätta mot dagens globala verklighet är kanske sådana krav revolutionära. De är under alla förhållanden närstående den av marxister så

2. Från Arkiv. Tidskrift för samhällsanalys nr 3 20I4, s. 72-73, DOI: http://dx.doi.org/ I0.13068/2000-6217.3.3. Se även Therborns andra artikel i samma nummer, "Nya massor? Motståndets sociala grundvalar" (DOI: http://dx.doi.org/IO.13068/2000-6217.3.4). 
SVENNING | MIN FÖRSTE MAGISTER I KRITISKT TÄNKANDE

kritiserade etiska socialismen, vars främste svenske socialdemokratiske företrädaren var Ernst Wigforss. Han är också berömd för sin formulering: "Ingenting är så praktiskt som en god teori."

Det är hoppfullt att Therborn allt oftare bjuds in till socialdemokratiska organisationer för att presentera sina teorier. 


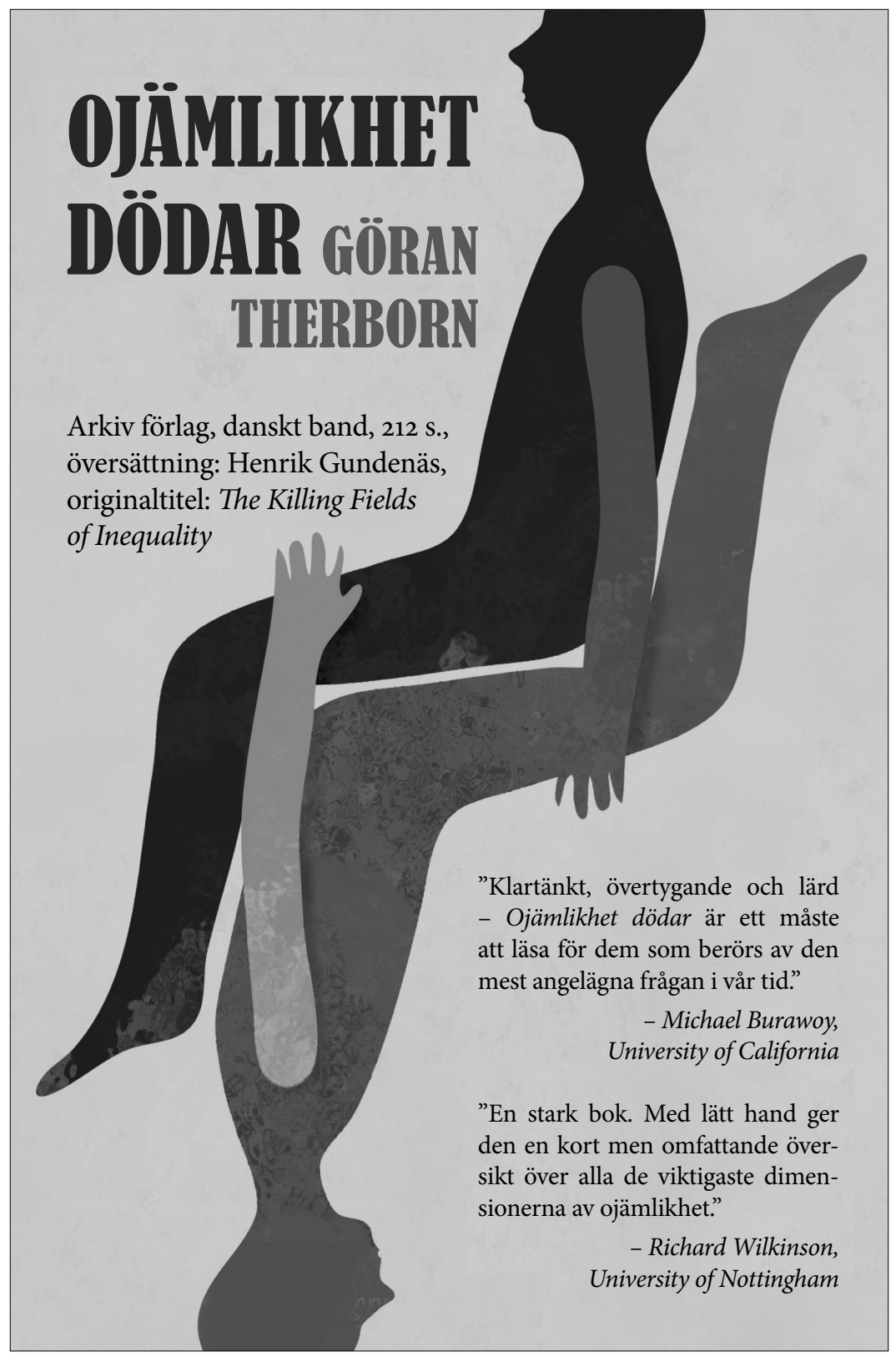

»Läs mer om boken på www.arkiv.nu« 